STUDIA NORWIDIANA 38:2020

DOI: https://doi.org/10.18290/sn.2038-7

ELIZA KĄCKA

\title{
ŚWIAT WZNIOSŁYCH UCZUĆ I DOBRYCH MANIER, CZYLI NORWIDOWSKIE PRAWO INWERSJI
}

\section{TAJEMNICA W SŁOWIE}

Dobrze ponad sto lat badań życia i dzieła Norwida przyniosło plon w postaci różnorodnej a ogromnej wiedzy, którą uznać można za dobrze udokumentowaną $\mathrm{i}-\mathrm{w}$ tym sensie - naukowo pewną. Do wiedzy tej wcale niełatwo coś jeszcze dodać. Jest jednak wiele obszarów, które domagają się spekulacji, przynoszącej wiedzę niepewną, lecz w przypadku tekstów, takich jak Tajemnica lorda Singelworth - niepewność to uzasadniona. Nie tylko dlatego, że w tytule tekstu znajdujemy słówko „tajemnica”" - niedające się zlekceważyć w świetle Norwidowskiej antropologii. Także dlatego, że kontekst paryski nie jest dla omawianego tekstu jedynie naturalnym kontekstem z epoki, lecz żywym tłem biograficzno-światopoglądowym. Brudny Paryż gałganiarzy ${ }^{2}$ to przecież także Paryż mieszkańca tego miasta, Norwida - a chociaż Tajemnica lorda Singelworth dzieje się w Wenecji ${ }^{3}$, sam tekst dałby się czytać z Paryżem II Cesarstwa wedtug Baudelaire'a pod ręką (podobnie zresztą Tajemnica Marii Roget Edgara Allana Poego, ulokowana w Paryżu, działa się w Nowym Yorku). Sama figura lorda, dekadencko-artystowska filozofia smaku, zmysł prowokacji i krajobraz, w którym palimpsesty śmietników

\footnotetext{
${ }^{1}$ Por. M. ADAMIEC, „,Tajemnica lorda Singelworth” albo metafizyka balonu, „Studia Norwidiana" 3-4: 1985-1986, s. 202.

${ }^{2}$ Por. W. Benjamin, Paryż II Cesarstwa u Baudelaire'a, w: TENŻe, Twórca jako wytwórca. Eseje i rozprawy, przeł. R. Reszke, Warszawa 2011, s. 64 i n. Tekst znany jest polskiemu czytelnikowi bardziej z poprzedniego przekładu, który skądinąd różni się od przekładu Reszkego większą liczbą śródtytułów i obecnością wstępnych passusów, których w nowym thumaczeniu nie ma. Rzecz należałoby porównać z oryginałem. Por. W. BenJAmin, Paryż II Cesarstwa wedlug Baudelaire'a, przeł. H. Orłowski, w: TENŻE, Twórca jako wytwórca, wyboru dokonał H. Orłowski, wstęp J. Kmita, przeł. H. Orłowski, J. Sikorski, S. Pieczara, Poznań 1975, s. 191 i n.

${ }^{3} \mathrm{Na}$ temat tego, po co Norwidowi Wenecja, spekulował m.in. Krzysztof Trybuś (Stary poeta. Studia o Norwidzie, Poznań 2000, s. 188 i n).
} 
odgrywają jedną z ról głównych, to tylko niektóre z przyczynków do uruchomienia paryskich tropów. Tajemnica ma jednak także wymiar odsłowny - i nie idzie mi wyłącznie o zagadkową przezwę, nazwę czy neologizm, lecz także o skojarzenie słowne lub kulturowe, które umyka naszej uwadze, pozostając zresztą wyłącznie możliwością. Tytułem wprowadzenia do rozważania o Tajemnicy lorda Singelworth umieszczam tu dwa przykłady małych odkryć.

Przykład pierwszy. Druga strofa wiersza Po balu, wyjętego, jak wiadomo, z fantazji Za kulisami, stanowi opis woskowanej posadzki, gdzie „tańcowałobyło wiele mask" (PWsz I, 318); po walcujących parach pozostały w opustoszałej sali już tylko zakreślone obuwiem kręgi. Kłopot interpretatorom przynosi charakter tej powierzchni: „na jasnej woskiem zwierzchni szyb”. Parkiet - bo marmurów się nie woskuje - nie przywodzi przecież na myśl szyby. Wyjaśnienie, jak się zdaje, zawiera poprzednia, pierwsza strofa, mówiąca o kontemplacji przedświtu przez okno. Podmiot liryczny stoi więc u okna (które wkrótce otworzy) i przypuścić można, że widzi w szybie odbicie podłogi za plecami. A zarazem - co każdy zna z doświadczenia - dostrzega poprzez szybę zarysy pobliskich dachów w pierwszym świetle poranka. Szyba jest lustrem półprzepuszczalnym. Obydwa obrazy nakładają się na siebie i tekst to oddaje. Nie jest więc tak, że patrzący stoi najpierw pośrodku sali, by wkrótce podejść do okna. Stoi przy oknie od początku. Jednak ten zarys sytuacji stanowi dopiero podstawę drugiego dwuwiersza drugiej strofy. $Z$ obrazu porysowanej podłogi da się bowiem coś wyczytać. Co? Tego poeta nie zdradza. Po co jednak mówić, że się coś wyczytało, skoro nie chce się powiedzieć, co? Zmierzam do spostrzeżenia, że Norwid jednak to mówi. Popatrzmy: „Czarodziejskich jakoby pisań tryb / Z ziemi do mnie mówił, jak z księgi” (PWsz I, 318). Spotykają się tu kręgi, czary, ziemia i tańce. W tym punkcie należy przypomnieć sobie, co to są tak zwane kręgi czarownic. Widuje się je na leśnych polanach, wyznaczone przez rosnące w kształt okręgu grzyby. Folklor wielu krajów, także polski, wiąże je z nocnymi pląsami czarownic. Kręgi takie stanowią więc ślad po sabacie. W świetle tego skojarzenia nieszczęsny bal maskowy w Hôtel Lambert, nieodwołany mimo świeżego zgonu Zygmunta Krasińskiego, otrzymuje - wyczytaną z podłogi zabójczo negatywną ocenę: był niczym innym jak manifestacją siły nieczystej, istnym sabatem. Że jednak nie sposób dowieść, iż Norwid zetknął się z przekazami folklorystycznymi na temat rytuałów czarostwa, interpretacja ta pozostać musi nie tylko jednym z fakultatywnych odczytań, lecz w większym stopniu niż kilka z nich zasila sferę wiedzy niepewnej.

Przykład drugi i krótszy. W wierszu Sfinks [I] spełnia się pewne proroctwo, którego znakiem jest zmartwychwstanie Archimedesa. Za chwilę odwaleniu ulegnie kamienna płyta na imaginacyjnym grobie uczonego: „gwinty jego śrub / 
Sklepień czarnych opowiada trzask" (PWsz I, 329). Niezwykła ta wizja nie straci zapewne nic ze swej magii, lecz stanie się po trosze bardziej zrozumiała, jeśli uświadomić sobie, że istnieje francuskie słowo cric, dziwnym trafem oznaczające zarówno „trzask”, jak i „lewar”. Lewar zaś, czyli dźwignia, za pomocą której grecki mędrzec podejmował się podnieść kulę ziemską, jest - obok wanny - jego emblematem. Śrubę Archimedesa Norwid mógł uważać - błędnie - za coś $\mathrm{w}$ rodzaju urządzenia, które zwiemy dziś podnośnikiem. Inaczej mówiąc, na kształt obrazu poetyckiego wpłynęła być może terminologia zaczerpnięta $\mathrm{z}$ języka, jakim się posługiwał na co dzień. Dowodu z nieświadomości przeprowadzić jednak nie można, hipoteza ta pozostać musi w obrębie wiedzy niepewnej.

Te dwie krótkie spekulacje interpretacyjne, niezwiązane tematycznie z $\mathrm{Ta}$ jemnica lorda Singelworth, nadają ton lekturze, której zamierzam się tu podjąć. Do tekstu Norwida dodaję bowiem kontekst, który jedynie może być, acz nie musi, wskazaniem interpretacyjnym dla konkretnego epizodu z tekstu autora Menego. Norwid jako obywatel świata literackiego, Norwid-modernista, wreszcie - Norwid-dziwak na miarę galerii społecznych kontestatorów końca XIX wieku domaga się od nas lektury niepokornej. Świadomej ironii, goryczy i żartu.

Juliusz Wiktor Gomulicki pisał w przedmowie do Trylogii włoskiej:

Norwid, pamiętający Swifta, a ponadto znający współcześnie publikowane Trzewia Lewiatana Wiktora Hugo oraz Wonie Paryża Ludwika Veuillot, tym skwapliwiej mógł zwrócić się w stronę tego rodzaju tematyki, która wydała mu się najbardziej odpowiednia do wyrażenia głębokiej pogardy, jaką odczuwał w owej chwili dla dziewiętnastowiecznej cywilizacji europejskiej, przede wszystkim zaś dla własnego społeczeństwa, które konsekwentnie wdeptywało go w ,śmiecie” i w „błoto”. Od takiego to społeczeństwa uciekał fantasta Singelworth i od takiego również uciekał Norwid $[\ldots]^{5}$.

Sugestia swego rodzaju paktu biograficznego Norwida z lordem Singelworth zostaje tu przez Gomulickiego związana - co ciekawsze od egzystencjalnego kodu wyrzutka - ze swego rodzaju filozofią nieczystości. Nie zapominajmy, że kanały (owszem, nieweneckie) i palimpsesty z historyczno-cywilizacyjnych odpadków to $\mathrm{w}$ zbliżonym przecież czasie jeden $\mathrm{z}$ ważnych wątków (i obrazów) w pisaniu nie kogo innego jak Bolesława Prusa ${ }^{6}$. U Norwida jednak wątek czy-

\footnotetext{
${ }^{4}$ Oczywiście, pojawiające się w tym wierszu słowo „gwinty”, kojarzące się ze śrubą, pozwala na inną lekcję tekstu, rodzimą.

${ }^{5}$ J.W. GomUlicki, O „Trylogii wtoskiej” Norwida. Geneza - kształtowanie - wymowa, [w:] C. NoRwID, Trylogia włoska, opracowanie tekstu, studium wstępne oraz wybór rysunków J.W. Gomulicki, Warszawa 1979, s. 44-45.

${ }^{6}$ Myślę m.in. o tekstach Pod szychtami czy Ogród Saski. Por. B. Prus, Pisma wszystkie. Humoreski, nowele, opowiadania, t. II, red. T. Żabski, Warszawa-Lublin 2015, s. 113-127.
} 
stości-nieczystości wchodzi w bardzo ścisły związek z filozofią osoby. Na jakiej zasadzie? Po pierwsze, skoro decydujemy się przyjmować całego człowieka, to bierzemy go nie tylko świeżym i wonnym. Po drugie, wątek czystości-nieczystości ma w sobie rebeliancki potencjał nicowania naszych przyzwyczajeń i przewartościowywania hierarchii. Bo to, co nieczyste, nie musi być tym, co brudne (i vice versa). Norwid-mieszkaniec Paryża, obserwator i ironista, powołujący się na biografie tak moralnie nieoczywiste jak biografia lorda Byrona, jest tym, który poznaje świat od jego strony kloacznej. I potrafi dostrzec w nim nie tylko chrześcijańską godność człowieka, lecz także fascynująco-niepokojącą sferę. Nieczystość pozwala zatem na taką grę znaczeń, która myśl o człowieku wpisuje w plan przewrotnego moralitetu. Moralitetu na wspak, pełnego ironii.

\section{INWERSJA}

Wrażliwość poetycka Norwida porządkuje jego uniwersum według pewnych widocznych regul, o przejawach których wiele już pisano. Norwidowskim prawem inwersji nazywam patronującą jego wyobraźni semiotyczną zasadę, że to, co wielkie, ujrzeć można właśnie w tym, co małe, to, co wieczne - w tym, co przelotne, to, co wzniosłe - w tym, co niskie, co głośne - w milczącym, słowem to, co znaczące, w tym, co nieznaczne. Nic nie jest więc do końca takim, jakie się wydaje, i nic nie bywa nigdy naprawdę banalne. Wybór tej perspektywy narzuca pisarstwu Norwida strategię poszukiwacza sensu, a jemu samemu - postawę ironisty ${ }^{7}$. Ekstrema bowiem nie tylko się stykają, ale i kompromitują. Nie dzieje się to, oczywiście, zawsze, ale zasadniczo wszędzie tam, gdzie przedstawiany bywa świat wzniosłych uczuć i dobrych manier - zatem tam, gdzie króluje nieautentyczność.

Toteż pozwolę sobie postawić tezę, że szczególnie wyraziście to prawo inwersji przejawia się w nowelistycznej trylogii włoskiej Norwida z lat osiemdziesiątych, szczególnie zaś w ostatniej - Tajemnicy lorda Singelworth. Fabuła tej prozy skupia się, co zawsze zauważano, na wspomnianym poszukiwaniu sensu, dużo słabiej jednak postrzegana bywa jej nieubłagana ironia ${ }^{8}$. A że świat wznio-

\footnotetext{
${ }^{7} \mathrm{O}$ postawie ironisty w kontekście instytucji nadawczej utworu pisze - w związku z Tajemnica lorda Singelworth - Sławomir Rzepczyński, O umyśle „,zgadobliwym”. „,Tajemnica lorda Singelworth”, „Studia Norwidiana” 14: 1996, s. 105 i n.

${ }^{8} \mathrm{Nie}$ jest tak, oczywiście, by sprawa ironii była interpretacyjnie zupełnie zaniedbana. Z ostatnich publikacji wart cytowania jest artykuł Ewangeliny Skalińskiej, Jeszcze o „,Tajemnicy lorda Singelworth”. Między ironia a autoironia, „Colloquia Litteraria” 2017, nr 1, s. $107-122$.
} 
słych uczuć i dobrych manier wyniesiony jest tam na niebywałe wyżyny, prawo inwersji poszukiwać każe w tekście stosownie kompromitującego te wytworności ekstremum.

W roku 1887 Oscar Wilde opublikował na łamach pisma ,The Court and Society Review", a w 1891 ogłosił książkowo nowelę Lord Arthur Savile's Crime: A Study of Duty. Jedna z postaci tej satyrycznej prozy, lady Windermere, wcielenie świata wzniosłych uczuć i dobrych manier, podsumowuje tam wróżbę chiromanty:

W przyszłym roku, na przykład, ma mi zagrażać wielkie niebezpieczeństwo, zarówno na lądzie, jak i na morzu, wobec czego mam zamiar zamieszkać w balonie i wciągać sobie na górę każdego wieczoru kosz z obiadem. Wszystko to jest wypisane na moim małym palcu czy też na dłoni, zapomniałam gdzie ${ }^{9}$.

Koncept ten z miejsca przywodzi na myśl mniej oczywiste praktyki Norwidowskiego lorda. Niemniej widać, iż jest to właśnie koncept, odwołanie do obiegowych opinii, że w kwestii dziwacznych obyczajów arystokrata brytyjski zdolny jest do wszystkiego. W wyobraźni zbiorowej epoki lord angielski to ekscentryk, figura tyleż komiczna, ile niepojęta. Tak przedstawia go Życie paryskie Offenbacha, tak wyobrażają sobie paryżanie członków snobistycznego Jockey Clubu, taką emblematyczną postać czyni w roku 1872 bohaterem swej powieści Jules Verne. Jego nieprzenikniony Phileas Fogg, Esq. z książki $W 80$ dni dookoła świata uznany być może za symbol dążenia przed siebie, jak lord Singleworth, czyli „Nieporównany”, to symbol dążenia wzwyż.

Zwracam tu uwagę, jak bardzo lord Singelworth i jego tajemnicze rytuały są kliszą literacką, a raczej, jak dalece należą do popularnego imaginarium. Wprowadzając ludowego improwizatora, który publicznie roztrząsa jego sekrety, Norwid daje do zrozumienia, że lord stanie się w Wenecji kolejną legendą miejską, na kształt więźniów Piombi czy skaczących z kampanili San Marco samobójców. Myśl tę podsuwa także zakończenie noweli. W interesie legendy jest nigdy nie pozbawić poczynań lorda aury tajemnicy ${ }^{10}$. Niemniej Norwid czyni wiele, by wykluczyć wszelkie wyjaśnienia tejże - prócz jednej. Dzięki dociekliwości carskiej tajnej policji weneccy plotkarze wiedzą, że gondola balonu nie zawiera żadnych przedmiotów niebezpiecznych, a jedynie „etruską okrągłą wazę albo porcelanową" (DW VII, 221). Niedyskrecji improwizatora Tony di Bona Grazia zawdzięczają ciekawscy wieść, iż z tejże gondoli upadł na wyspę Murano papier zawierający treść, niepisaną jednak, a przez to podobny palimpsestom,

${ }^{9}$ O. WILDE, Zbrodnia lorda Artura Savile'a. Studium o obowiazku, przeł. H. Seidel, w: TENŻe, Eseje. Opowiadania. Bajki. Poematy proza, red. J. Żuławski, Warszawa 1957, s. 159.

${ }^{10}$ Por. S. RZEPCZYŃSKI, O umyśle „,zgadobliwym”, s. 105. 
dający do myślenia osobom posiadającym nosy. Sam lord natomiast w ramach wyjaśnień czyni niejasne aluzje do sił trawienia, pozorności higieny miejskiej oraz Ksantypy, wylewającej nocnik ${ }^{11}$ na głowę Sokratesa.

\section{PRZYJACIEL BAUDELAIRE'A}

Swoje codzienne zabiegi lord Singelworth odprawiał - mówi nowela - w Kairze, Konstantynopolu, Moskwie, Wiedniu, Paryżu i Odessie - słowem wszędzie. Wenecja - przypuścić można - scenerią jego poczynań stała się głównie za sprawą dwuznaczności, jaką w jej przypadku podsuwa słowo „kanalizacja”. Jak wiadomo, sprawa ta stanowi dla niej problem do dziś dnia. Sam wyżej nakreślony wątek kojarzy się jednak raczej z Paryżem. I nie dotyczy bynajmniej angielskiego arystokraty - tego, wraz z Wenecją, uznać można za kamuflaż - lecz postaci realnej, która dostąpiła godności paryskiej legendy miejskiej.

Ów paryski literat, który przeszedł do cokolwiek skandalicznej legendy, miał w kwestii czystości poglądy najzupełniej wobec lorda Singelworth przeciwne. Nazywał się Philoxène Boyer (1827-1867), a żywot jego przedstawia SylvainChristian David, znawca twórczości Lautréamonta, w biografii Philoxène Boyer: Un sale ami de Baudelaire ${ }^{12}$ wydanej w roku 1987. Wyczytać $\mathrm{z}$ niej można, iż „brudny przyjaciel Baudelaire’a” był synem wybitnego filologa klasycznego o równie niezwykłym imieniu Austremoine. W wieku lat dziewiętnastu szybciej nawet niż Baudelaire, bo w dziewięć miesięcy, przepuścił spadek po ojcu w wysokości osiemdziesięciu tysięcy franków. Odtąd żył w nędzy, nękając przyjaciół - do których prócz autora Kwiatów zła zaliczali się Arsène Houssaye, Théodore de Banville, Flaubert, Gautier, Barbey d'Aurevilly, Villiers de l'Isle Adam i wielu pomniejszych - swymi planami literackimi, których niezdolny był przelać na papier, oraz niepowstrzymanym kultem Victora Hugo. Potrafił, idąc tyłem przed rozmówcą przez pół Paryża, wyrecytować z pamięci całą swoją komedię tak, jak gdyby ją czytał. Pozostawił jednak tylko tom kiepskich wierszy, parę bezwartościowych wodewilów, garść korespondencji i album z przyjacielskimi wpisami najświetniejszych piór ówczesnej Francji. Był prawdopodobnie ostatnią osobą, z którą przed swym samobójstwem rozmawiał Nerval. Zmarł, nie dożywszy czterdziestki, w dwa miesiące po Baudelairze.

\footnotetext{
${ }^{11}$ Ściślej: „urnę pełną domowych nieczystości” (DW VII, 231).

${ }^{12}$ Por. S.-Ch. DAvid, Philoxène Boyer: Un sale ami de Baudelaire, Paris 1987. Por. zwłaszcza s. 201-202 i 205.
} 
Rzecz w tym jednak, że zasłynął z niebywałego brudu. Kultywował go nie tylko z niedostatku, lecz dla idei. $Z$ wodą, nie mówiąc o mydle, nie stykał się nigdy, znajomi komentowali z fascynacją powolne ciemnienie jego białego niegdyś szala. Zauważyli też, że nosi coraz większe buty - zapytany, wyjaśnił, że to dlatego, iż nigdy nie obcina paznokci u nóg. Z charakteru skromny i nieśmiały, pysznił się swym niechlujstwem, stając się prekursorem szkoły dandysów abnegacji, jak później Alfred Jarry, Max Jacob czy Paul Léataud. Na orbitę legendy wprowadziła go jednak około roku 1855 przygoda w hôtel Thierry przy ulicy Lacépède, gdzie mieszkał $\mathrm{i}$ - jak opowiada Charles Asselineau - unikając gospodarza, zakradał się na swą mansardę przez okno kuchni. Żeby jednak skorzystać z wygódki, musiałby przejść przez jadalnię. Gdyby nawet zostawić na boku dług wobec hotelarza, w swej wstydliwości wzdragał się zmierzać tam i wychodzić na oczach pań. W tej sytuacji zaczął kupować dziennik „La Patrie”, który, jako prorządowy, był najtańszy, zawijać weń, wedle słów Asselineau, „les bizarres effets de la nature" ${ }^{\prime 3}$, i z wyżyn szóstego piętra ciskać pakiety na ulicę. Po jakimś czasie zorientował się jednak, że go to na dłuższą metę zdekonspiruje. Zaczął wtedy zawiniątkami, krągłymi jak kule armatnie, zapełniać ścienną szafę. Gdy wreszcie pod nieobecność poety hotelarz przysłał komornika, ten chciał zająć meble, lecz właściciel wyjaśnił, że należą do niego. Nie pozostało nic innego, jak opieczętować ruchomości. Na polecenie komornika ślusarz otworzył szafę i jako jej jedyna zawartość ukazało się ponad sto wyżej wymienionych kul. Komornik odstąpił od czynności, izba była zaś tak zapowietrzona, że nikt nie chciał jej wynająć i Boyer, nadal nie płacąc, zamieszkał w niej na powrót.

Historia ta, z gatunku takich, jakie opowiadają sobie literaci, musiała mieć pewien powab jeszcze w trzy dekady później, gdy uczęstowano nią paryskiego bywalca, Oscara Wilde'a, który, złagodziwszy ją odpowiednio, nie oparł się chęci ulokowania jej w formie aluzji w swojej opowiastce. Stąd wniosek, że wieść o przygodzie paryskiego pisarza $\mathrm{z}$ produktami przemiany materii mogła nie ominąć i Norwida, który aż nadto znane sobie żałosne realia, przeniesione po latach w świat wzniosłych uczuć i dobrych manier, spożytkował jako skryty motyw najbardziej szyderczej ze swych nowel. Zgodnie z Norwidowskim prawem inwersji tylko ten wymiar trywialności zrównoważyć mógł obłąkany idealizm lorda Singelworth, co „zbyt wysoko się podnosi, ażeby dotyczyła go nieczystość" ${ }^{14}$. Nawet to bowiem, co plugawe i najniższe, wywyższa się na

\footnotetext{
${ }^{13}$ Por. tamże, s. 205.

${ }^{14} \mathrm{~W}$ tekście głównym pozwalam sobie na parafrazę. Cytat brzmi dosłownie: „Jednym słowem: za wysoko ja się podnoszę, ażeby dotyczyła mię nieczystość!...”. Por. DW VII, 231.
} 
wyżynach: „Co ci się podoba, stamtąd rzuć, a potem o safirowej nocy letniej patrz na spadający aerolit... jakże on jest pięknym!..."

Tak niespotykane napięcie ekstremów trąci zresztą, co sugeruje Norwid, patologią (nie w sensie obyczajowo-moralnym, a bardziej klinicznym). Lord Singelworth jest inny nie tylko dlatego, że chce, lecz zapewne i dlatego, że musi ${ }^{16}$. W roku 1888 psychiatra doktor Alexandre Cullerre (1849-1934) ogłosił traktat Les frontières de la folie, już trzy lata później opublikowany w Warszawie w przekładzie doktora Ludwika Wolberga jako $U$ wrót obłędu ${ }^{17}$. Dzieło to podejmuje kwestię, jak dziś się mówi, normy psychicznej, czyli zachowań nietypowych. Oto jeden z przypadków:

Pan de Puy..., oficer legii honorowej, były podintendent wojskowy, po wystąpieniu ze służby zamieszkał w dawniejszym kościele w B... i wiódł tam życie nader ekscentryczne i ordynarne. Żył z ludźmi najgorszego gatunku, chadzał po ulicy w koszuli, bez majtek i pończoch, w tymże kostiumie stawał na balkonie i publicznie załatwiał wszystkie swe potrzeby. Rodzina poleciła zbadać go przez doktorów Rousselin'a i Lunier'a ${ }^{18}$.

Wniosek z tych badań-oględzin okazał się zaskakujący dla lekarzy, lecz jakże charakterystyczny dla Cullerre'owskiego typu ekscentryka: „Wygląd pomieszkania pana de Puy... [...] zdradza człowieka o bardzo dziwacznych zwyczajach; przebywa on wśród okropnej nieczystości i nieporządku nie do opisania"19.

Te dziwactwa i wariacje, obok wielkiego sprytu i wykształcenia, zadziwiały każdego. Ciekawą cechą tego umysłu było to jeszcze, że chętnie zdzierał urok poezji ze wszystkiego i sprowadzał wszystkie wzniosłe fakty do poziomu najzwyklejszego realizmu i materializmu. Tak np. po długim, entuzjastycznym wychwalaniu jakiegoś utworu poetyckiego, nagle kończył swą apologię słowami: ,pomyślcie jednakże, że autor tego arcydzieła chodzi codziennie do wygódki”20.

Rzec można, że pacjent ów padł ofiarą nazbyt rozwiniętego prawa inwersji. I w tym punkcie to, co medyczne, przecina się z tym, co literackie. W roku 1732 Jonathan Swift ogłosił poemat The Lady's Dressing Room, którego bohater imieniem Strephon zakrada się do buduaru swej nieprzytomnie wielbionej, boskiej Celii i przez długie sto siedemnaście wierszy asystuje jej toalecie. Jego wzrok błądzi wśród przepoconych koszul, zapchanych łupieżem grzebieni, z za-

${ }^{15}$ DW VII, 231-232.

${ }^{16} \mathrm{~W}$ sprawie niemożności i przymusów por. K. SAMSEL, Norwid-Conrad. Epika w perspektywie modernizmu, Warszawa 2015, s. 199 i n.

${ }^{17}$ A. CULLERRE, U wrót obłędu. Studyum psychologiczne, przeł. L. Wolberg, Warszawa 1891.

${ }^{18}$ Tamże, s. 122.

${ }^{19}$ Tamże, s. 123-124.

${ }^{20}$ Tamże, s. 121. 
tłuszczonych ścierek, wysmolonych ręczników, zasmarkanych chustek do nosa, słoików pełnych plwocin, kosmetyków z psich wnętrzności i upapranych zjełczałym sadłem ówczesnych odpowiedników biustonoszy. Aż w końcu powala go najsroższe odkrycie: „Oh! Celia, Celia, Celia shits!” (w. 118). Rażony prawem inwersji, rozjątrzony idealizm sięga bruku. Na szczęście w sto pięćdziesiąt lat później zjawia się lord Singelworth, by raz jeszcze wznieść go na wyżyny. Oto, czemu Juliusz Wiktor Gomulicki w swój wstrzemięźliwy sposób nazwał nowelę Tajemnica lorda Singelworth swiftowską ${ }^{21}$. Czy miał rację?

\section{APENDYKS. NIECZYSTOŚĆ VERSUS MYDŁO}

Czytelnicy Norwida pamiętają świetnie wiersz Purytanizm. Oto fragment:

Słowem - że w mydło wierzę niezachwianie,

Lecz gdyby kto chciał, abym przez to samo

Wziął się do pracy: stawić z nim mieszkanie

Bogów, gościnne tryumfalną bramą,

$\mathrm{Z}$ tak niesłychanie przeczystej materii,

Jak purytanizm, to... zrobiłbym może

Nie kościół, ale - utrapienie Boże,

Alabastrowe jak śniegi w Syberii!

$$
\text { (PWsz II, 67-68) })^{22}
$$

Wiersz ten, zawarty w liście do M. S. (Mariana Sokołowskiego), powstał w roku 1865, być może zatem pod wrażeniem dopiero co przeczytanej - gdy dobiegł kresu dramat powstania - Historii literatury angielskiej Hyppolite'a Taine'a (1863). Szyderczy fragmentami wywód wiersza uznać można za reminiscencję wykładu, jaki sławne dzieło Taine’a poświęca mentalności purytańskiej, a który dla Francuza stanowić mógł skądinąd, by tak rzec, laicki egzorcyzm wciąż żywego w rodzimej kulturze ducha Port-Royalu. Wiersz Norwida, jak łatwo zauważyć, posiada strukturę sylogizmu - kursywy zaznaczają przesłankę mniejszą (Primo) i wniosek (Ergo) - brak tylko przemilczanej przesłanki większej: Secundo. Nietrudno jednak odnaleźć miejsce, gdzie włącza się ona w tok rozumowania. To miejsce, gdzie ideologia czystości nie cielesnej już, lecz duchowej, ukazuje swój opresyjny charakter. W tym punkcie otworzyć należy książkę Taine'a i pod wyobrażenia dla Norwida, gdy pisał, oczywiste, podłożyć słowa filozofa kultury:

\footnotetext{
${ }^{21}$ J.W. GOMULICKI, $O$,, Trylogii wtoskiej”, s. 45.

${ }^{22}$ O Purytanizmie pisał ostatnio Jan Zieliński, Stearynowe utrapienie, [w:] „,Klucze od Echa” - Osobność - Wiersze Cypriana Norwida, red. E. Kącka, Kraków 2018, s. 93-102.
} 
Usta (purytanów - E. K.) oduczają się śmiechu, duchy omieniałe (tak w tekście - E.K.) i pobladłe tkwią wzrokiem tylko w przerażającym przedmiocie oczekiwania swego, a myśl na jednym tylko zatrzymuje się pytaniu: „Czy sędzia zechce mi przebaczyć?”. [...] Purytanin potępieniem ogarnia teatry, światowe zabawy i zbytki [...]. Cała istota ludzka zewnętrzna i cielesna ulega pogardzie i zdeptaniu, na korzyść istoty wewnętrznej i duchowej, która sama jedna ma tylko trwałość. Ze wszystkiego, co zawiera w sobie dusza ludzka, pozostają tylko pojęcia o Bogu i sumieniu, sumieniu które jest przerażonym i chorym $[\ldots]^{23}$.

Pod dziewiczą czystością tego ideału kryje się - konkluduje poeta - „,ierniowy dyjadem" (PWsz II, 68), korona męczeństwa, w gruncie rzeczy, dobrowolnego. Stąd wniosek, owo Norwidowskie Ergo, „Że marmur - marmur, zaś mydło jest mydło" (PWsz II, 68): poświęcenia nadmierne i, rzeklibyśmy dziś, prowokowane, za podszewkę psychologiczną mają nie co innego, jak pychę. Ideał czystości separuje wyznawcę od świata i spraw jego, zamyka go w widnokręgu własnego, wiecznie rozjątrzonego, sumienia, a co najgorsze - wynosi ponad bliźnich, już nie tak doskonałych. Toteż purytanin pozostawia ich własnym, niewątpliwie zasłużonym losom. Umywa ręce, jako: „Że - robić z mydła, to - umywać ręce !" (PWsz II, 68). W tym więc sensie ideał absolutnej autopuryfikacji jest, co paradoksalne, poniekąd mydlany i zatrąca małodusznym gestem Piłata. Mało tego: poświęcenie w stylu purytańskim, gest pychy, jest zarazem wewnętrznie jałowe. Na to właśnie wskazują podane przez Taine’a rozliczne przykłady, z których warto przytoczyć choć jeden:

Uczony pewien, nazwiskiem Leighton, piętnaście tygodni przebył w psiej budzie, w kajdanach, bez dachu nad głową, bez pościeli i ognia; gdy włosy wypadły mu z głowy i skóra na ciele popękała w listopadowe chłody, przywiązano go do pręgierza, ochłostano, piętnowano na czole, poczem obcięto mu uszy, rozcięto nos i wtrącono go na lat osiem naprzód do jednego więzienia, a potem na zawsze do drugiego. Wielu $\mathrm{z}$ tych ludzi umierało, $\mathrm{i} \mathrm{w}$ dodatku z radością, na gorejącym stosie. Religia była dla nich umową, przymierzem, które zawarli z Bogiem i którego dotrzymać powinni byli aż do ostatniej syllaby i litery, wbrew wszystkiemu, i tak zupełnie, jakby to był najdokładniej spisany kontrakt ${ }^{24}$.

Jednakże konkluzja Taine’a, zaraz w kolejnym zdaniu, jest druzgocąca: „Podziwu i zarazem pożałowania godna niezłomność sumienia, które pławi się w drobiazgach, obok wyznawców tworzy gadułów i zrzędów, a w przyszłości ma obok męczenników wytworzyć tyranów!"25. Oto, czemu w swym wierszu nad nieludzką czystość w biały atłas odzianych dziewic (jak z obrazu Burne-Jonesa) Norwid

\footnotetext{
${ }^{23}$ H.A. TAINE, Historya Literatury Angielskiej, przeł. E. Orzeszkowa, Warszawa 1900, s. 456.

${ }^{24}$ H.A. TAINE, Historya Literatury, s. 459.

${ }^{25}$ Tamże.
} 
przedkłada trud utaplanych po łokcie w błocie pracownic czystości doczesnej wiejskich praczek znad stawu. I im właśnie dedykuje wynalazek mydła.

\section{BIBLIOGRAFIA}

ADAMIEC M., „Tajemnica lorda Singelworth” albo metafizyka balonu, „Studia Norwidiana” 3-4: 1985-1986, s. 201-215.

BeNJAmin W., Paryż II Cesarstwa u Baudelaire'a, w: TENŻe, Twórca jako wytwórca. Eseje i rozprawy, przeł. R. Reszke, Warszawa 2011, s. 55-132.

Benjamin W., Paryż II Cesarstwa wedlug Baudelaire'a, przeł. H. Orłowski, w: TENŻe, Twórca jako wytwórca, wyboru dokonał H. Orłowski, wstęp J. Kmita, przeł. H. Orłowski, J. Sikorski, S. Pieczara, Poznań 1975, s. 182-235.

Cullerre A., U wrót obtędu. Studyum psychologiczne, przeł. L. Wolberg, Warszawa 1891.

DAVID S.-Ch., Philoxène Boyer: Un sale ami de Baudelaire, Paris 1987.

GoMULICKI J.W., O „Trylogii wtoskiej” Norwida. Geneza - ksztaltowanie - wymowa, [w:] C. NoRwID, Trylogia włoska, opracowanie tekstu, studium wstępne oraz wybór rysunków J.W. Gomulicki, Warszawa 1979, s. 5-25.

PRUS B., Pisma wszystkie. Humoreski, nowele, opowiadania, t. II, red. T. Żabski, WarszawaLublin 2015.

RZEPCZYŃSKI S., O umyśle „zgadobliwym”. „Tajemnica lorda Singelworth”, „Studia Norwidiana" 14: 1996, s. 105-112.

SAMSEL K., Norwid - Conrad. Epika w perspektywie modernizmu, Warszawa 2015.

SKALIŃSKA E., Jeszcze o „,Tajemnicy lorda Singelworth”. Między ironiq a autoironia, „Colloquia Litteraria" 2017, nr 1, s. 107-122.

TAINE H.A., Historya Literatury Angielskiej, przeł. E. Orzeszkowa, Warszawa 1900.

Trybuś K., Stary poeta. Studia o Norwidzie, Poznań 2000.

WILDE O., Zbrodnia lorda Artura Savile'a. Studium o obowiazku, przeł. H. Seidel, w: TENŻE, Eseje. Opowiadania. Bajki. Poematy proza, red. J. Żuławski, Warszawa 1957, s. 157-202

ZIELIŃSKi J., Stearynowe utrapienie, [w:] „Klucze od Echa” - Osobność - Wiersze Cypriana Norwida, red. E. Kącka, Kraków 2018, s. 93-102.

\section{ŚWIAT WZNIOSŁYCH UCZUĆ I DOBRYCH MANIER, CZYLI NORWIDOWSKIE PRAWO INWERSJI}

\section{S t r e s z c z e n i e}

Artykuł stanowi przede wszystkim propozycję nowego odczytania Tajemnicy lorda Singelworth w kontekście Norwidowskiej antropologii z jednej, a tła historyczno-kulturowego z drugiej strony. Rozumienie „czystości” przez Norwida, niewolne od inspiracji ewangelicznych, wchodzi w ciekawe zależności z realiami, w których przyszło funkcjonować nie tylko samemu poecie, ale też bohaterowi jego zagadkowej noweli. Odczytanie Tajemnicy lorda 
Singelworth skupia się wokół obrazu lotu balonem, z którego lord - wedle tej interpretacji, nieodosobnionej zresztą w norwidologii - zrzuca papier zawierający treść natury fizjologicznej. Scena ta umieszczona zostaje w kontekście innych literackich lotów balonem, a także w związku z ekscentrycznym zachowaniem lorda - skonfrontowana z manifestacjami dziwności, jakie w Paryżu XIX wieku urządzał przyjaciel Baudelaire'a, Philoxène Boyer. Singelworth wypada zatem na jednego $z$ ciekawych dziwaków literatury dziewiętnastowiecznej. Jednocześnie pozostaje jedną z figur, w związku z którymi przywołać można - wyprowadzone w artykule - norwidowskie prawo inwersji.

Słowa kluczowe: czystość; antropologia; Paryż XIX wieku; ironia; inwersja.

\title{
THE WORLD OF LOFTY FEELINGS AND GOOD MANNERS, OR NORWID'S LAW OF INVERSION
}

\author{
$\mathrm{S} \mathrm{u} \mathrm{m} \mathrm{m} \mathrm{a} \mathrm{r} \mathrm{y}$
}

First of all, the presented article offers a novel interpretation of Lord Singleworth's Secret in the context of Norwid's anthropology on the one hand, and a historical and cultural background on the other. Norwid's understanding of "cleanliness," which was inspired in some measure by the Gospels, had interesting connections with the life circumstances of Norwid himself and the main character of his puzzling short story. The reading of Lord Singleworth's Secret revolves around the image of a balloon flight during which the lord-according to this interpretation, not alien in Norwidology — throws a paper with "physiological content." This scene is put in the context of other literary balloon flights, and also, due to Lord Singleworth's eccentric behaviour, confronted with the manifestations of bizareness organized by Baudelaire's friend Philoxène Boyer in the 19th century. So it seems that Singleworth is one of the most interesting weirdos of the 19th-century literature. Nonetheless, he remains one of the characters for whom we may invoke Norwid's law of inversion - inferred in the article.

Key words: cleanliness; anthropology; 19th-century Paris; irony; inversion.

ELIZA KĄCKA - adiunkt na Wydziale Polonistyki UW. Autorka książek naukowych Stanisław Brzozowski wobec Cypriana Norwida (2012) oraz Lektura jako spotkanie. Brzozowski - tekst-metoda (2017), a także tomów prozatorskich Elizje (2017) i po drugiej stronie siebie (2019). Redaktorka antologii poezji najnowszej Poeci i poetki przekraczaja granice (Katowice: FA-art, 2011) oraz wyborów poezji mniej współczesnej (m.in. Cypriana Norwida Klucze od Echa-Osobność-Wiersze, 2018). Członkini Zarządu Głównego TLiAM; e-mail: eliza.kacka@gmail.com. 